the pharmaceutical company concerned. Nevertheless, the Department of Health and Social Security insists that the reporting doctor should remain anonymous when details of adverse reactions are passed to pharmaceutical companies, and any representations to allow the name of the doctor to be conveyed to the company have failed.

I suggest, therefore, that the yellow report form should be produced in triplicate rather than singly. The reporting doctor would then retain a copy of what he had reported. The top copy would still go to the Committee on Safety of Medicines, and the second copy, without the name of the patient, would go to the Association of the British Pharmaceutical Industry, which would act as a clearing house for forwarding to the relevant company. Just as the top copy is Freepost to the committee so the second copy would be Freepost to the association. The major advantage of producing a form in triplicate would be that the decision to send a second copy to the pharmaceutical company would remain with the reporting doctor. Obviously, I would hope that most second copies would indeed be sent to manufacturing companies. The introduction of the triplicate form and the cohort identification system would enhance the notification of adverse drug reactions and would make a system that is already probably better than any other in Europe the best in the world.

FRANK WELLS

\footnotetext{
Association of the

British Pharmaceutical Industry,

London SW1A 2DY
}

\section{Primary pulmonary hypertension}

SIR,-Drs Celia Oakley and A Rozkovec (10 January, p 122) regard long term prostacyclin infusion as an unnecessary, complicated, and dangerous treatment for primary pulmonary hypertension. We believe that we are the only group with experience of this form of treatment and that their conclusions are speculative.

The patients seen at Papworth have been referred for heart-lung transplantation. In those whose haemodynamic function deteriorates despite treatment with oral vasodilators, including nifedipine, and who fall into the poor prognosis group we use a prostacyclin infusion to buy time and improve the quality of life. Such patients have a pulmonary arterial blood oxygen saturation of less than $63 \%$ and only a $17 \%$ chance of surviving for three years. ${ }^{1}$ Prostacyclin sustains these patients during the necessarily long time (up to two years) that they spend on the waiting list for the operation. For obvious reasons the number of patients so treated is very small, but our experience suggests that prostacyclin is no more complicated and dangerous to use than the previously ineffective oral vasodilators. $^{2}$

The other point that needs clarification is Drs Oakley's and Rozkovec's belief that the gas transfer for carbon monoxide is always reduced in primary pulmonary hypertension, a belief not shared by others. ${ }^{3.5}$ It is fairly straightforward to explain why patients with pulmonary vascular disease, including pulmonary hypertension, may have a normal carbon monoxide transfer factor. ${ }^{4}$ If the capillaries are not directly affected by the obliterative or obstructive lesions they will contain red blood cells capable of taking up carbon monoxide. Filling of these capillaries depends on the various pressures acting on the pulmonary vascular bed and may be augmented by collateral blood flow from bronchial arteries. ${ }^{46}$ In addition, such patients also seem to have a normal ventilation to perfusion ratio, ${ }^{78}$ suggesting that many will indeed have a normal carbon monoxide transfer factor.
Finally, Drs Oakley's and Rozkovec's distinction between thromboembolic veno-occlusive disease and primary pulmonary hypertension according to the response to vasodilators is unfortunately spurious. It probably requires the detailed pathology of the patients' vascular disease to be correlated with premorbid or pretransplant physiological results. Such studies are only just beginning, and initial evidence suggests that all the pathological types of the syndrome show some degree of vasodilation with treatment.9 Studies of thromboembolic disease certainly indicate that pulmonary hypertension may be partially reversible with vasodilators. ${ }^{10}$

Tim HigenbotTAM JOHN WALLWORK

Regional Departments of Respiratory Physiology

and Cardiothoracic Surgery,

Papworth Hospital,

Cambridge CB3 8RE

1 Fuster V, Steele PM, Edwards WD, Gersch BJ, McGoon MD, Frye RC. Primary pulmonary hypertension: a natural history Frye RC. Primary pulmonary hypertension: a natural his
and importance of thrombosis. Circulation 1984;70:580-7.

2 Jones $\mathrm{K}$. Treatment of primary pulmonary hypertension with intravenous prostacyclin. $\mathrm{Br}$ Heart $\mathcal{f}$ (in press).

3 Gazetopoulos N, Salonides N, Davies H. Cardiopulmonary function in patients with pulmonary hypertension. $\mathrm{Br}$ Heart f 1974;36:19-28.

4 Nadel JA, Gold WM, Burgess JH. Early diagnosis of chronic pulmonary vascular disease. Am f Med 1968;44:24.

$5 \mathrm{Kafen}$ ER. Respiratory function in pulmonary thromboembolic disease. Am 7 Med 1969;47:904-15.

6 West JB, Dollery CT, Naimark A. Distribution of blood flow in isolated lung: relation to vascular and alveolar pressures. f Appl Physiol 1964;19:713-20.

7 Dantzker DR, Bower JS. Pulmonary vascular tone improves VA/Q matching in obliterative pulmonary hypertension. f Appl Physiol 1981;51:607-13.

8 Dantzker DR, Bower JS. Mechanisms of gas exchange abnormality in patients with chronic obliterative pulmonary vascular disease. $f$ Clin Invest 1979;64:1050-5.

9 Higenbottam TW, Fitzpatrick M, Wallwork J. Survival from primary pulmonary hypertension. Thorax (in press).

10 Dantzker DR, Bower JS. Partial reversibility of chronic pulmonary hypertension caused by pulmonary thromboembolic disease. Am Rev Respir Dis 1981;124:129-31.

${ }_{*}^{* *}$ This correspondence is now closed.-ED, $B M \mathcal{F}$.

\section{HIV transmitted by kissing}

SIR,-Dr J W G Smith has responded (14 February, $p$ 446) to my letter published in the Guardian, in which I challenged the Chief Medical Officer or any of the medical and scientific experts advising the government on the acquired immune deficiency syndrome (AIDS) to cite "even one published paper which gives detailed laboratory evidence that there is any cell-free infectious virus (human immunodeficiency virus or HIV) in semen; or cite even one published paper specifying the number of cells in semen containing either viral RNA, or pro-viral DNA, or both."

Although Dr Smith gave 16 references, he failed to cite a single relevant paper in response to the challenge, for the simple reason that no such paper exists. He cited two studies in support of his claim that HIV "can be detected fairly easily in semen from infected people." 12 Only two people were described in the first study and one person in the second. In no case was any cell free virus detected in the semen, nor did spermatozoa contain any cell associated virus, nor could HIV antigen be detected in any lymphocytes found in the seminal fluid. Only after lymphocytes from semen had been cocultured for six to 11 days in the presence of other lymphoid cells and of $T$ cell growth factor interleukin-2 were HIV antigens detected in any of them. These two studies, published in October 1984, proved no more than that at least one lymphocyte in a single specimen of semen from each of three men contained HIV proviral DNA. No viral RNA, or antigen, or any virion, could be detected until the semen had been subjected to prolonged, highly artificial laboratory conditions.

In the two and a half years since these two papers were published no further detailed laboratory study of the presence of HIV in semen has been published. Professor Jay Levy (personal communication) has detected HIV in the semen of only $10 \%$ of more than 50 men who had HIV in their blood. He has already published the finding that HIV can be detected in semen only if the lymphocytes in it "are cultured under optimal laboratory conditions"3; usually none can be found.

Understanding of the pathogenesis and transmission of a viral disease requires knowledge of the quantity of virus shed into bodily fluids, the duration and variability of shedding, the balance between cell free infectious virions and cell associated virus, the stability of the virus in the environment, and the route of entry into the host. This well established principle has been neglected by many experimental and medical scientists who, like Dr Smith and other members of the government's expert advisory group on AIDS, have accepted uncritically the hypothesis that "HIV is transmitted primarily by sexual intercourse." Many have been so certain of the validity of this flawed hypothesis that they have assumed that experimental studies support it, even though they do not.

Nineteen experimental scientists said in Nature: "High titres of cell free infectious virions can be obtained from AIDS patients' semen." ${ }^{4}$ The papers in Science cited in support of this fact showed that no cell free infectious virion had been found in semen. ${ }^{12}$ Eight medical and experimental scientists wrote in the Lancet that HIV "circulates as cell free virus in... seminal fluid." They adduced as evidence the paper in Science, in which the authors reported that "because of the toxic effects of semen on target cells used for these isolations, it is unclear whether there is also cell free (HIV) in seminal plasma."2

Dr Robert Gallo, in a paper delivered to a plenary session of the second international conference on AIDS in Paris in June 1986, said: "We think that semen is a particularly rich source of virus," although he gave no scientific evidence to substantiate these thoughts. The BBC's Radio 1 programme Play SafeAIDS and You (13 December 1986) asserted that "virus is present in semen in very high concentrations." Sir Donald Acheson, Chief Medical Officer Dr.Anthony Pinching, a member of the government's advisory group on AIDS; and Dr John Dawson, head of the scientific division of the BMA, were the medical experts speaking on the programme.

As to the infectivity of saliva, Dr Smith wrote: "The difficulty in determining the relevance of such in vitro studies is evident in the reference ${ }^{6}$ quoted by Dr Seale on virus in saliva. The method of culture employed in that study could not have differentiated between cell free and cell associated virus." The relevant words in the text of the Groopman study are: "Saliva samples were diluted to a final volume of $2 \mathrm{ml}$ in complete growth medium, incubated for 2 hours at $37^{\circ} \mathrm{C}$, and centrifuged at $1000 \mathrm{~g}$ for 10 minutes at $4^{\circ} \mathrm{C}$. Pelleted materials were fixed for electron microscopy, and supernatant fluids were filtered $(0.45 \mu \mathrm{m})$ and used for transmitting virus to fresh peripheral blood lymphocytes." 6 Similar words were used in the caption to table $I$ in the paper. Groopman and his colleagues make it crystal clear that cell free infectious virions were obtained directly from the saliva of eight of 18 men who had antibodies to HIV in their blood. Furthermore, figures $1 \mathrm{c}$ and $1 \mathrm{~d}$ are electron micrographs of "mature virus particles... obtained from the saliva of patient No 8."

There are three essential properties that a parasitic microbe must have in its interaction with the human host if the disease it causes is to be transmitted characteristically by sexual intercourse. Firstly, the microbe must be shed in large quantities in genital secretions and not in other body fluids. Secondly, it must be able to enter a person only through the genitalia. Thirdly, it must perish within a few minutes outside the body. If any of these properties is missing the microbe may be transmitted by various means in addition to sexual intercourse. A major flaw in the hypothesis that HIV is transmitted primarily by sexual intercourse is that none of the pathogenic properties essential to make it so is present.

When HIV is indeed transmitted during sexual intercourse nobody knows if it is usually passed on in saliva, or in the serum from minor abrasions, or in genital secretions, or in some other way. Consequently, there are good reasons to doubt the claim made by experts advising the government 
that the AIDS epidemic can be controlled by a massive public education campaign advising people to use condoms. This campaign is well and truly founded on ignorance.

JoHN SEALE

London WIN 1AE

1 Zagury D, Bernard J, Leibowitch J, et al. HTLV-III in cells cultured from semen of two patients with AIDS. Science 1984;226:449-51.

2 Ho DD, Schooley RT, Rota TR, et al. HTLV-III in the semen and blood of a healthy homosexual man. Science 1984;226: and 3 .

3 Levy JA, Kaminsky LS, Morrow WJW, et al. Infection by the retrovirus associated with acquired immune deficiency syndrome. Ann Intern Med 1985;103:694-9.

4 Ratner L, Haseltine W, Patarca R, et al. Complete nucleotide sequence of the AIDS virus, HTLV-III. Nature 1985;313: 277-84.

5 Zagury D, Fouchard M, Vol JC, et al. Detection of infectious HTLV-III/LAV virus in cell-free plasma from AIDS patients. Lancet 1985; ii:505-6.

6 Groopman JE, Salahuddin SZ, Sarngadharan MG, et al. HTLVIII in saliva of people with AIDS related complex and health homosexual men at risk for AIDS. Science 1984;226:447-9.

SIR,-Dr W G Smith (14 February, p 446) suggests that the human immunodeficiency virus (HIV) is not transmitted by mouth to mouth kissing, an opinion voiced in the government's leaflet on the acquired immune deficiency syndrome (AIDS).

The leaflet, however, also says: "Nor is it safe to share a toothbrush . . . of someone who is infected." Using a carrier's toothbrush carries risk because small quantities of infected blood from the gums might be transmitted to the uninfected user's bloodstream through the gums during brushing. There is scarcely less risk of transmission of HIV when a carrier kisses an uninfected partner mouth to mouth after both have cleaned their teeth using their own toothbrushes. Infected blood from the carrier's gums could readily pass into the uninfected partner's bloodstream through abrasions caused by the toothbrush. Dr Smith's statement that "there are no well documented cases where infection has been attributed to kissing" applies equally to shared toothbrushes, yet the government's AIDS advice sanctions the one but advises against the other.

The Department of Health and Social Security has, in fact, explicitly recognised and stated the possible danger from infected saliva in its guidance notes for doctors and dentists: "The virus has also been isolated from saliva, tears, and breast milk. I may occur in other bodily fluids and could possibly be spread by these." Later, the notes say that there is no substantial evidence for such spread, but they nevertheless recommend to dentists that "in view of the aerosols containing blood and saliva that may be generated by low and high speed dental drills, ultrasonic scalers, and irrigation/air syringes, the wearing of protective eyewear and masks is essential."'

It would surely be more prudent for the DHSS to give the general public the same warnings against AIDS in saliva as it has given to its own doctors and dentists.

Christopher MONCKTON

Richmond,

Surrey TW106DJ

1 Department of Health and Social Security. AIDS-don't die of ignorance. London: HMSO, 1986.

2 Department of Health and Social Security. Guidance for surgeons, anaesthetists, dentists and their teams in dealing surgeons, anaesthetists, dentists and their teams in dealing
with patients infected with HTLV III. London: HMSO, 1986.

SIR,-Dr J H G Smith discussed only the role of saliva as the infective fluid, the infectivity of which for human immunodeficiency virus is uncertain

The infectivity of contaminated blood, however, is not in doubt. The transmission of AIDS after blood transfusion has been documented, ${ }^{1}$ as has seroconversion after needlestick accidents. ${ }^{2-4}$ The high risk state of intravenous drug abusers suggests that fairly small amounts of blood, such as might contaminate used needles, may carry infective doses of HIV.

During open mouthed kissing the juxtaposition of teeth and delicate vascular oral and glossal mucous membranes carries the risk of mucosal injury and bleeding for both partners. In addition, oral lesions, such as herpes labialis, aphthous ulcers, gingivitis, and even toothbrush abrasions, must expose capillaries and are all very common. It therefore seems likely that open mouthed kissing may transmit HIV, but, as Dr Smith points out, this is obscured by the fact that those who engage in such kissing also probably have sexual intercourse.

Should we really wait for four or five years until epidemiological studies prove that a significant number of careful condom users still develop overt AIDS before we make this connection?

Royal Infirmary,

L A KAY

1 Curran JW, Lawrence DN, Jaffe H, Kaplan J, Zyla LD, Chamberland $M$. Acquired immunodeficiency syndrome assochamberland $M$. Acquired immunodeficiency syndrom

Weiss SH, Saxinger WC, Richtman D, et al. HTLV III infection among health care workers: association with needlestick in juries. FAMA 1985;254:2089-93.

3 Henderson DK, Saah AJ, Zak BJ, et al. Risk of nosocomial infection with HTLV III/LAV in a large cohort of intensively exposed healthcare work

Ma pay E. Co-operative needlestick survellance group. O pation risk of the acquired immun pational risk of the acquired immunodeficiency syndrome among healthcare workers. N Engl f Med 1986;314:1127-32. Moss AR. AIDS and intravenous drug use: the real heterosexua epidemic. Br Med f 1987;294:389-90.

\section{Death in the clouds}

SIR,-Dr Frank S Preston's reply to Drs PJC Chapman and DA Chamberlain (7th February, p 374) raised some important questions. The patient's illness, as described, was most unusual and must have been perplexing at the time, but if the cause of death was myocardial infarcation then the final collapse is likely to have been due to ventricular fibrillation. If this is to be treated successfully a rapid response is crucial. The prospects of success are almost non-existent within seven or eight minutes of the start of the emergency, and I believe that the reassurance generated by $D r$ Preston's telemetry to a consultant cardiologist is ill founded.

Dr Preston may not understand the philosophy behind automatic and semiautomatic ("advisory") defibrillators. This type of equipment has been developed and is marketed by several leading manufacturers precisely to obviate the need for high skills and constant practice in those who use it. Modern technology enables the machines to "diagnose" ventricular fibrillation with remarkable precision. Skill is still required but only in reading, and the message "Defibrillation required" has a stark simplicity that cabin staff at $\mathbf{3 0 0 0 0}$ feet will appreciate.

Pinderfields General Hospital,

A K MARSDEN

Wakefield,

West Yorkshire WF1 4DG

\section{Early emergency care}

SIR, - The study by Dr J M Rawles and colleagues (7 February, $p$ 352) of the use of defibrillators by general practitioners highlights what an effective lifesaving technique this is. Cardiopulmonary resuscitation is useless unless a defibrillator can reach the patient rapidly, and the longer cardio- pulmonary resuscitation continues the less chance defibrillation has of being effective. Ideally, a defibrillator and a trained user should be available wherever sudden death is likely to occur. In particular, I believe that all ambulances should carry defibrillators, which all ambulancemen should be trained to use. When I tried to implement this idea in Alton in 1977 I met with much opposition.

Alton is a market town which, with its surrounding villages, has a population of about 25000 and is 15 miles from Basingstoke District. Hospital. In 1980, after three frustrating years of negotiations with the ambulance authorities, the local ambulancemen raised money by public donation and equipped their two ambulances with Lifepack-5 defibrillators. The 13 station members were given a course in cardiopulmonary resuscitation by their training officer, and I instructed them in the recognition of cardiac arrhythmias and in defibrillation. The men were then examined by a cardiologist, who was satisfied with their ability to recognise and treat ventricular fibrillation. At this point the ambulance authorities forbade them to use the defibrillators.

When the inevitable happened and a patient went into ventricular fibrillation while being collected from his home by the ambulance the crew acted briskly and performed defibrillation. The local newspaper's article on this patient's golden wedding celebrations after his return from hospital was followed by a change of heart by the ambulance authorities, who decided that the Alton crews (but no others) could use the defibrillators. Several prominent local citizens have lived to be grateful for this ruling.

In 1983 Wessex Regional Health Authority started a scheme to incorporate cardiac training with defibrillation into advanced training, which also includes intubation and infusion. As only a few ambulancemen get places on such a course many will never learn this skill. This is a pity because defibrillation is so much easier to learn and to apply than intubation and infusion and has recently been shown by Anderson $e t$ al to be far more likely to save lives out of hospital.

Drs Chapman and Chamberlain are to be applauded for introducing the cabin staff of British Caledonian Airways to defibrillation. ${ }^{2}$ How much more necessary it is to do the same for the members of our ambulance brigades.

H J N BETHELL

Health Centre,

Alton,

1 Anderson IWR, Black RJ, Urquhart JD, et al. Early emergency care study: the potential and benefits of advanced prehospital care. BrMed f 1987;294:228-31.

2 Chapman PJC, Chamberlain DA. Death in the clouds. BrMed $\mathcal{f}$ $1987 ; 294: 181$.

\section{Occult chlamydial ophthalmia in men with} non-gonococcal urethritis

SIR,-Dr E F Monteiro and colleagues (7 February, p 349) reported on occult chlamydial ophthalmia in men with non-gonococcal urethritis. Tullo and colleagues estimated that about one in 300 adults with a genital chlamydial infection $(0.3 \%)$ develops inclusion conjunctivitis, ${ }^{1}$ and it would be reasonable to assume that the proportion developing occult disease is greater. But is occult chlamydial eye infection in eight of 60 men with non-gonococcal urethritis (13\%), as reported by Dr Monteiro and colleagues, reasonable, particularly when Chlamydia trachomatis was isolated from the genital tract of only about $27 \%$ of the men? The inference from this is that about every other man with chlamydial non-gonococcal 